Intecoms: Journal of Information Technology and Computer Science

Volume 1 Nomor 2, Desember 2018

e-ISSN : 2614-1574

p-ISSN : 2621-3249

DOI : https://doi.org/10.31539/intecoms.v1i2.295

\title{
MEMBANGUN WEB KONTEN MANAJEMEN SISTEM SECARA DINAMIS DENGAN BAHASA PEMROGRAMAN PHP FRAMEWORK CODEIGNITER DENGAN DATABASE MARIADB
}

\author{
BUILD WEB CONTENT SYSTEM MANAGEMENT DYNAMIC WITH \\ PROGRAMMING LANGUAGE PHP FRAMEWORK CODEIGNITER WITH \\ MARIADB DATABASE
}

\author{
Rio Bayu Sentosa \\ Universitas Putra Indonesia YPTK Padang \\ riobayusentosa@upiyptk.ac.id
}

\begin{abstract}
The development of science at a time with rapid technological advancements to be applied in all fields. In addition to the creation of computers and the rapid development of the internet network today is also equipped with a web-base application that can be used to disseminate information quickly. The purpose of this study is that researchers want to build a Content Management System that aims specifically for the development of applications based on Rapid Application Development with the basic standard Application Portal News. Based on research that has been done and taking data samples at the Office of the Governor of West Sumatra by using the Action Research, library and laboratory research methods, it is known that the Content Management System that the researchers designed can be used as a news portal capable of disseminating information. Designing a Content Management System that uses the Codeigniter Framework, is able to provide convenience in developing the system in the future and can be used to build other website applications based on Rapid Application Development.
\end{abstract}

Keywords: CMS, CodeIgniter, MariaDB, News Portal

\section{ABSTRAK}

Berkembangnya ilmu pengetahuan pada saat dengan kemajuan teknologi yang pesat untuk diaplikasikan disemua bidang. Selain telah terciptanya komputer dan majunya perkembangan jaringan internet saat ini juga dilengkapi dengan sebuah aplikasi web-base yang dapat digunakan untuk menyebarkan informasi dengan cepat. Tujuan penelitian ini adalah peneliti ingin membangun Content Management Sistem yang bertujuan khusus untuk pembangunan aplikasi berbasis Rapid Application Development dengan basic standar Aplikasi Portal Berita. Berdasarkan penelitian yang telah dilakukan dan mengambil sampel data di Kantor Gubernur Sumatera Barat dengan menggunkan metode penelitian Action Research, pustaka dan laboratorium, maka diketahui bahwa Content Management System yang peneliti rancang dapat digunakan sebagai portal berita yang mampu menyebarkan informasi. Perancangan Content Management System yang menggunakan Framework Codeigniter, mampu memberi kemudahan dalam pengembangan system di masa mendatang dan dapat digunakan untuk membangun aplikasi website lainnya yang berbasis Rapid Application Development.

Kata Kunci: CMS, CodeIgniter, MariaDB, Portal Berita

\section{PENDAHULUAN}

Dewasa ini dalam menghadapi persaingan ketat dibutuhkan sistem informasi yang akurat, cepat, tepat dan mudah dipahami. Al Fatta (2007) mendefinisikan sistem informasi sebagai alat untuk menyediakan informasi dan data sehingga bermanfaat bagi yang memerlukannya. Tujuan sistem informasi ini adalah untuk menyajikan informasi guna mengambil keputusan pada perencanaan, pemarkarsaan, dan pengorganisasian.

Perkembangan ilmu pengetahuan dan teknologi telah memperlihatkan kemajuan yang pesat untuk 
diaplikasikan disemua bidang. Selain telah terciptanya komputer dan internet saat ini juga dilengkapi dengan sebuah aplikasi web-base dan didukung oleh Framework. Framework adalah sebuah kerangka kerja ataupun urutan-urutan dalam pekerjaan yang penggunaannya bertujuan untuk mengurangi kesalahankesalahan dari aktivitas-aktivitas yang sering dilakukan pada saat pelaksanaan proses pengembangan website (Wibirama, 2007). Beberapa Framework yang kita kenal saat ini seperti CodeIgniter, Cake PHP, Simphony, Kohana, dan Zend Framework.

Pembuatan website berbasis Content Management System (CMS) sebagai tools atau alat bantu yang memudahkan kepada user dalam melakukan pengelolaan, maintenance, mengedit konten dan modul serta membuat perubahan isi konten dan memperbarui data yang ada untuk ditampilkan pada sebuah website. Hal ini dapat dilakukan oleh developer maupun penggunanya. Beberapa jenis Content Management System yang dikenal saat ini seperti: Joomla, Drupal, Wordpress, Mambo, Balitbang, Lokomedia dll.

Dalam pembuatan Content Management System (CMS) perlu dilengkapi oleh Database sebagai media yang digunakan untuk penyimpanan konten yang telah dibuat. Salah satu database yang dapat digunakan adalah MariadDB yang mampu menunjang proses kerja Content Management System tersebut. Database MariaDB merupakan pengembangan dari database terdahulunya yaitu MySQL. Keunggulan dari database MariaDB adalah cara pemakaiannya lebih mudah dipahami, pengaksesan data stabil serta dapat memuat data lebih banyak.

Pada penelitian yang dilakukan, penulis ingin membuat sebuah Content
Management System dengan berbagai kegunaan dan kemudahan khususnya untuk Apalikasi berbasis Rapid Application Development (RAD), seperti pembuatan Sistem Informasi Akademik, Sistem Informasi Penjualan, dan Aplikasi yang dibuat dengan menggunakan sistem Rapid Application Development lainnya, tapi default dari Content Management System ini berupa Portal Berita. Sehingga penggunaan Content Management System untuk berbagai aplikasi berbasis web-base dapat memberikan kemudahan bagi pihak pengembang atau development (peneliti) tanpa harus memulai dari awal untuk membuat aplikasi lain yang dibutuhkan dan diharapkan aplikasi tersebut dapat diintegrasikan ke dalam Content Management System yang telah dibuat oleh peneliti.

\section{METODE PENELITIAN}

Untuk melakukan penelitian memerlukan data-data sebagai bahan yang digunakan untuk mendukung penelitian, untuk itu penulis menggunakan beberapa cara sebagai berikut :

Penelitian Lapangan (Field Research)

Penelitian yang dilakukan untuk membuat sebuah Website Content Management System yang mengunakan framework CodeIgniter dalam pembangunan Aplikasi berbasis RapidApplication Development dengan basic standar Portal Berita di Kantor Gubernur Sumatera Barat.

\section{Penelitian Perpustakaan (Library Research)}

Penulis melakukan penelitian dengan melakukan tinjauan ke pustaka guna mempelajari beberapa buku maupun literature-literatur yang berhubungan dengan pembuatan penelitian ini. Adapun beberapa buku tersebut diantaranya adalah buku-buku 
yang berhubungan dengan Content Management System, OOP, Framework CodeIgniter, MariaDB dan juga bukubuku lainnya yang dirasa perlu dalam penunjangan pembuatan penelitian ini.

\section{Penelitian Laboratorium (Laboratory Research)}

Merupakan tahap penelitian yang dilakukan dengan cara research labor Komputer guna mempraktekkan langsung hasil dari analisa yang bertujuan untuk menguji kebenaran sistem yang dirancang. Adapun hardware dan software yang digunakan dalam penelitian laboratorium ini adalah sebagai berikut :

$$
\text { Perangkat keras yang }
$$

dipergunakan : Microprosesor Intel Intel(R) Core(TM) i3 CPU M 370 @ 2.40GHz, Memory : 2GB.

Perangkat lunak yang dipergunakan : Sistem Operasi Windows 7, Web browser : Mozilla Firefox 19.0 b5, Aplikasi PHP, Xampp 1.8.1, MariaDB, Editor : NetBeans IDE 7.0.1, StarUml dan software pendukung lainnya.

\section{HASIL DAN PEMBAHASAN \\ UML (Unified Modelling Language) \\ Unified Modelling Language}

(UML) adalah bahasa yang telah menjadi standar untuk memodelkan suatu software ataupun aplikasi dalam bentuk beberapa diagram yang bersifat Objek Oriented. Berikut DiagramDiagram yang terdapat pada UML :

\section{Use Case Diagram}

$$
\text { Use case diagram }
$$
menggambarkan fungsionalitas pada suatu sistem. Use case merepresentasikan sebuah interaksi antara aktor dengan sistem. Aktor adalah sebuah entitas user yang berhubungan dengan sistem untuk melakukan pekerjaan-pekerjaan tertentu.Use case merupakan sebuah pekerjaan tertentu, misalnya login ke sistem, lihat laporan dan sebagainya.

\section{Class Diagram}

Class Diagram akan menggambarkan struktur sistem dari segi pendefenisian kelas yang akan dibuat untuk membangun sistem.

\section{Statechart Diagram}

Statechart diagram akan
menggambarkan transisi dan
perubahan keadaan (dari satu state ke
state lainnya) suatu objek pada
sistem sebagai akibat dari stimuli
yang diterima.

\section{Activity Diagram}

Activity diagram akan
menggambarkan berbagai alir
aktivitas dalam sistem yang sedang
dirancang, bagaimana masing-
masing alir berawal, decision yang
mungkin terjadi, dan bagaimana
mereka berakhir.

\section{Sequence Diagram}

$$
\begin{aligned}
& \text { Sequence diagram akan } \\
& \text { menggambarkan interaksi antar } \\
& \text { objek di dalam dan di sekitar sistem } \\
& \text { (termasuk pengguna, display, dan } \\
& \text { sebagainya) berupa message yang } \\
& \text { digambarkan terhadap waktu. }
\end{aligned}
$$

\section{Collaboration Diagram}

Collaboration diagram juga menggambarkan interaksi antar objek seperti sequence diagram, tetapi lebih menekankan pada peran masing-masing objek dan bukan pada waktu penyampaian message.

\section{Konsep Dasar Aplikasi Web}

HTML (HyperText Markup Language) adalah merupakan bahasa program untuk membuat suatu web yang sangat awal. Pada perkembangan selanjutnya, sejumlah skrip dan objek 
dikembangkan untuk memperluas kemampuan HTML. Aplikasi web dapat dibagi menjadi dua bagian yaitu Web Statis dan Web dinamis.

Kekurangan web statis adalah pada memelihara web atau program secara terus menerus untuk mengikuti setiap perubahan yang terjadi. Maka diperlukan web dinamis yang selalu mengikuti perubahan pada sistem atau program.

Pada penelitian Wardhani (2011) banyak dukungan database dalam membangun website dinamis yang interaktif seperti : Microsoft Access, SQL Server dan lainnya.

\section{CodeIgniter}

CodeIgniter adalah sebuah framework PHP open source yang dikembangkan oleh EllisLab. Framework ini sudah mendukung konsep MVC (Model View Controller) yang membedakan antara logika dan tampilan, sehingga pemrosesan aplikasi bisa dipecah-pecah menjadi beberapa bagian yang lebih spesifik. Selain itu, CodeIgniter juga telah menyediakan berbagai library yang siap pakai dan memungkinkan proses pembuatan aplikasi web menjadi lebih cepat.

Pada penelitian sebelumnya, telah banyak yang merancang suatu web menggunakan framework ini yaitu Octafian (2015) membangun web jual beli atau pun toko online yang dikenal dengan istilah ecommerce menggunakan framework codeigniter dan Pamungkas (2015) menggunakan framework ini membangun SMS Gateway berbasis Gammu.

\section{Metode Pembuatan Aplikasi}

MVC adalah sebuah metode untuk membuat sebuah aplikasi dengan memisahkan data dari database (Model), tampilan (View) dan bagaimana logika untuk memprosesnya
(Controller). Konsep MVC ini diperkenalkan dengan tujuan untuk memudahkan bagi para pengembang aplikasi berbasis web dalam mengembangkan aplikasinya. Untuk memahami metode pengembangan aplikasi berbasis MVC, diperlukan pengetahuan tentang pemrograman berbasis objek (OOP). Implementasi model ini sudah dilakukan oleh penelitipeneliti seperti Hidayat dan Surarso (2012) dalam merancang sistem kuis online adaptif, Prabowo (2015) juga merancang web ecommerce dengan metode ini.

Seiring dengan perkembangan teknik pemrograman, saat ini banyak aplikasi-aplikasi yang dikembangkan untuk mempermudah developer dalam pembuatan sebuah aplikasi website. Banyak kemudahan yang ditawarkan oleh aplikasi tersebut, misalnya sudah disediakan berbagai macam library dan plugins yang siap pakai sehingga pengembang tidak perlu bersusah payah membangun aplikasi web mulai dari awal lagi. Ketika menggunakan aplikasi yang berbasiskan MVC, programmer harus mengikuti aturan-aturan yang sudah disediakan di dalamnya.

\section{Content Management System (CMS)}

Dengan meningkatnya kebutuhan masyarakat dalam informasi maka para penyedia dan pengembang tekonologi informasi terus mengembang poduk terbaru dalam jenis perangkat lunak yang membuat penguna dapat mengunakannya semudah mungki. Content Management System atau lebih populer dengan singkatan CMS pertama kali muncul sebagai jawaban atau solusi dari kebutuhan manusia akan penyediaan informasi yang sangat cepat 


\section{Database MariaDB}

MySQL adalah DBMS yang populer dan banyak digunakan oleh programmer. Dulunya MySQL adalah salah satu product dari Sun MicroSystem dan dikembangkan oleh komunitas. Akan tetapi sejak Sun MicroSystem diakuisisi oleh Oracle, beberapa produk dari Sun MicroSystem ada beberapa yang menjadi berbayar. Oleh karena itu pendiri dan pengembang MySQL membuat forking dari MySQL yaitu MariaDB. MariaDB adalah DBMS hasil forking dari DBMS MySQL. Jadi syntax query yang digunakan hampir sama.

\section{Use Case Diagram}

Use case diagram pada sistem ini dapat dilihat pada gambar 1:

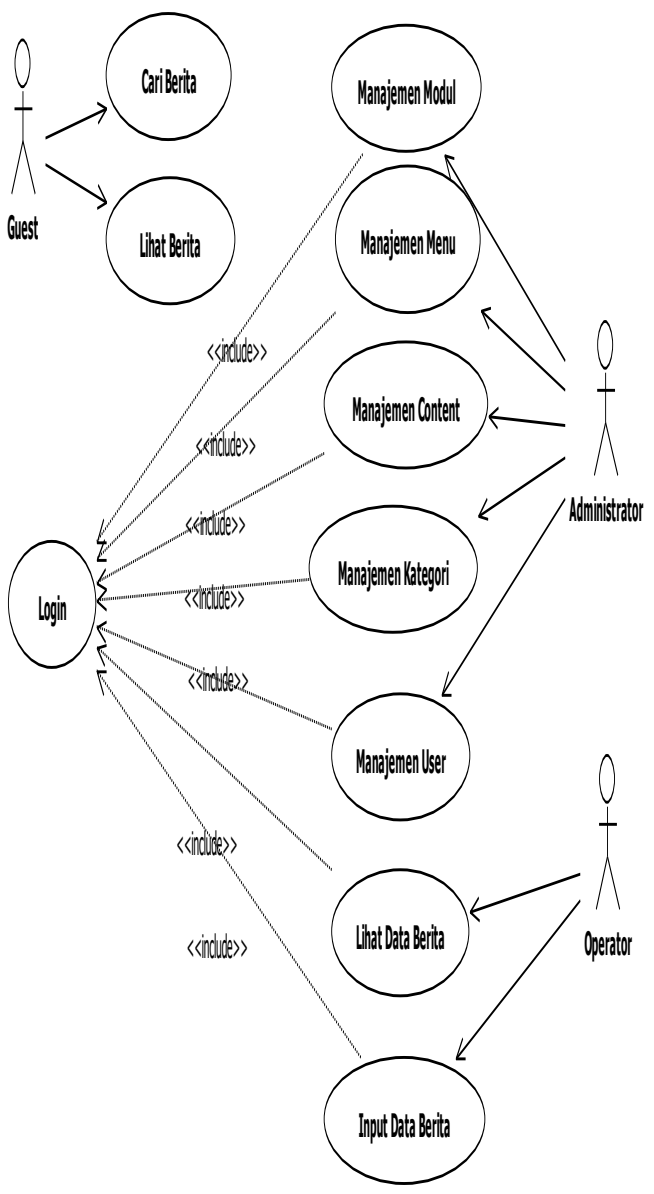

Gambar. 1 Use case Diagram

\section{Class Diagram}

Class diagram dari perancangan Web Content Management Systemdapat dilihat pada gambar 2:

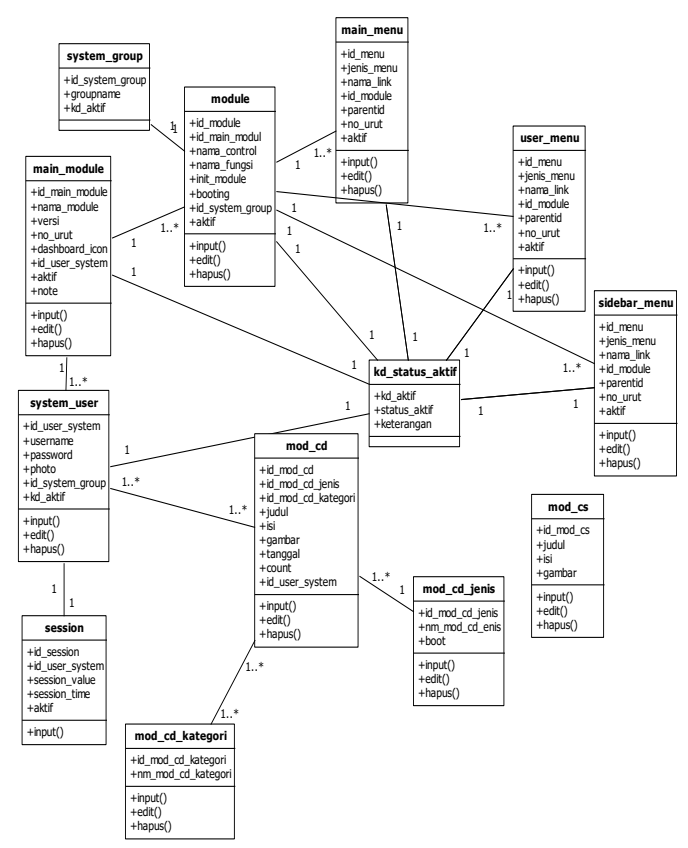

Gambar. 2 Class Diagram

\section{Activity Diagram}

1. Activity Diagram Administrator Activity diagram administrator dapat dilihat pada gambar 3:

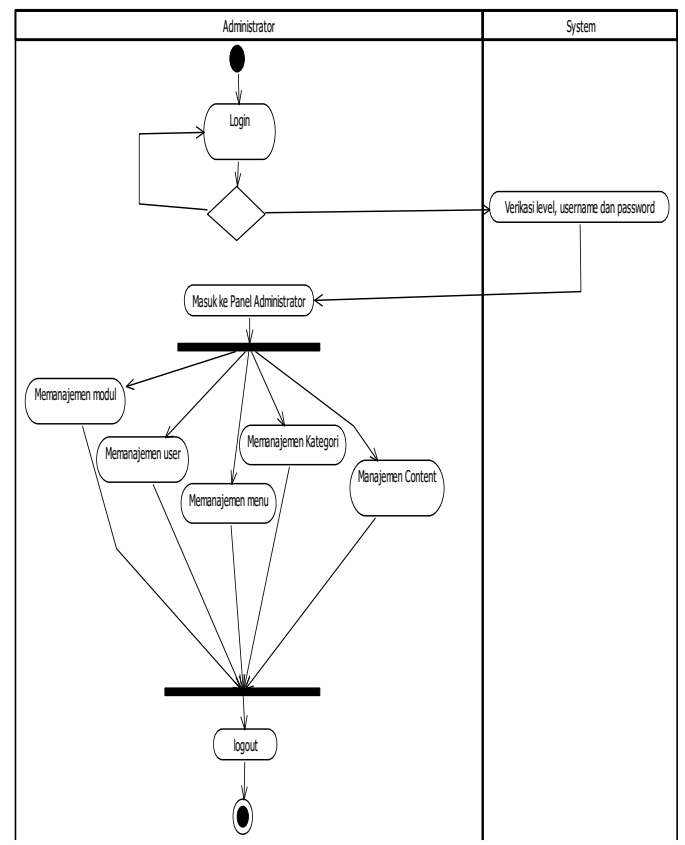

Gambar. 3 Activity Diagram Administrator 
2. Activity Diagram Operator Activity Diagram Operator dapat dilihat pada gambar 4 .

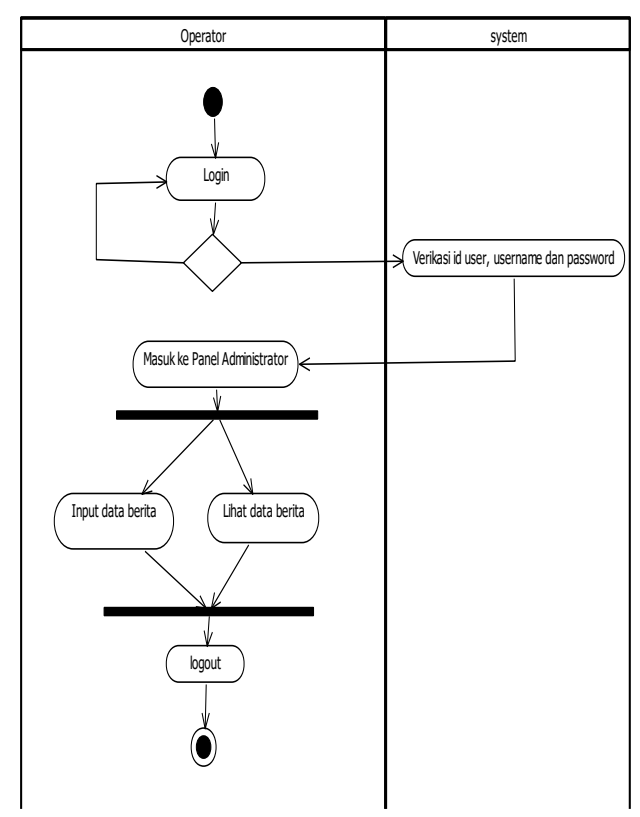

Gambar. 4 Activity Diagram Operator

\section{Activity Diagram Guest}

Activity Diagram Guest dapat dilihat pada gambar 5:

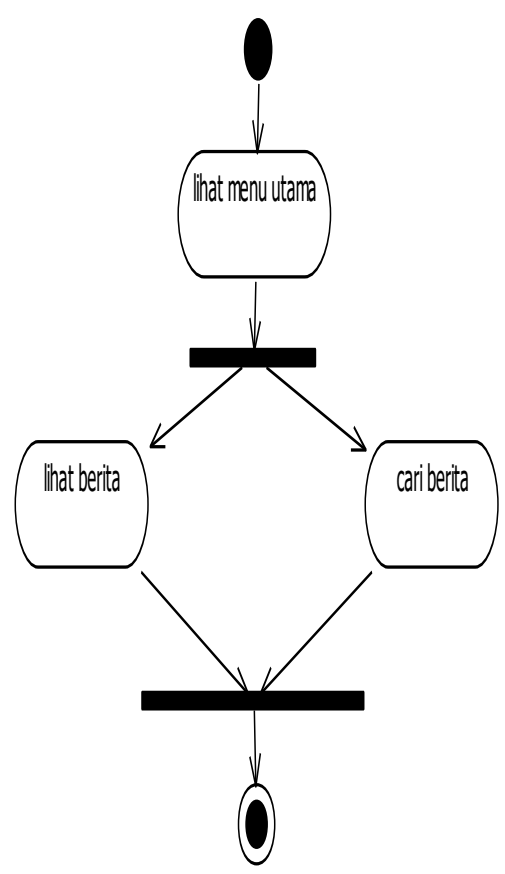

Gambar. 5 Activity Diagram Guest
Implementasi dan Pengujian Sistem Halaman Dashboar Administrator

Tampilan Halaman Dashboard Administrator terlihat pada gambar 6.Berikut:

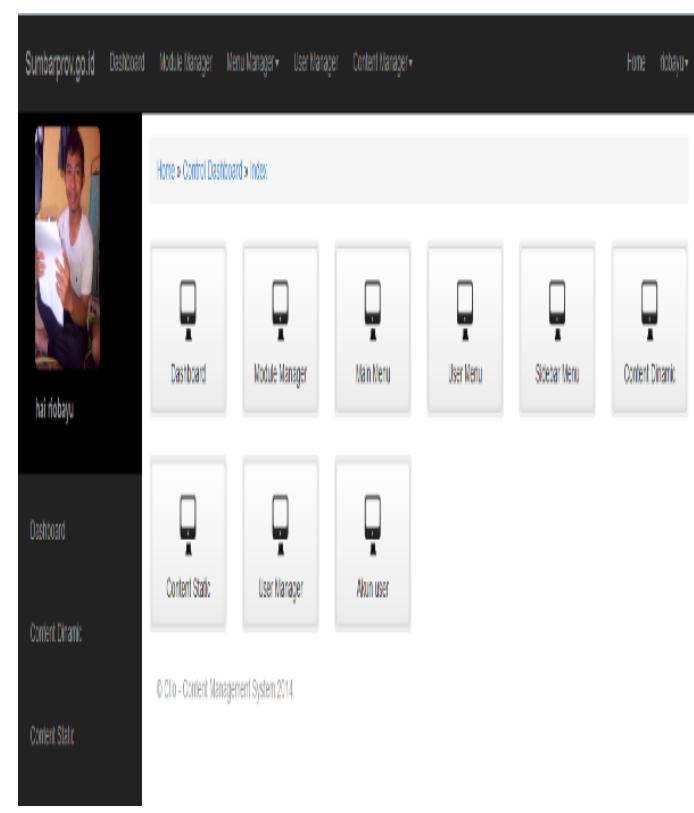

Gambar. 6 Halaman Dashboard Administrator

\section{Halaman Dashboard Operator}

Tampilan Halaman Dashboard Operator terlihat pada gambar 7berikut :

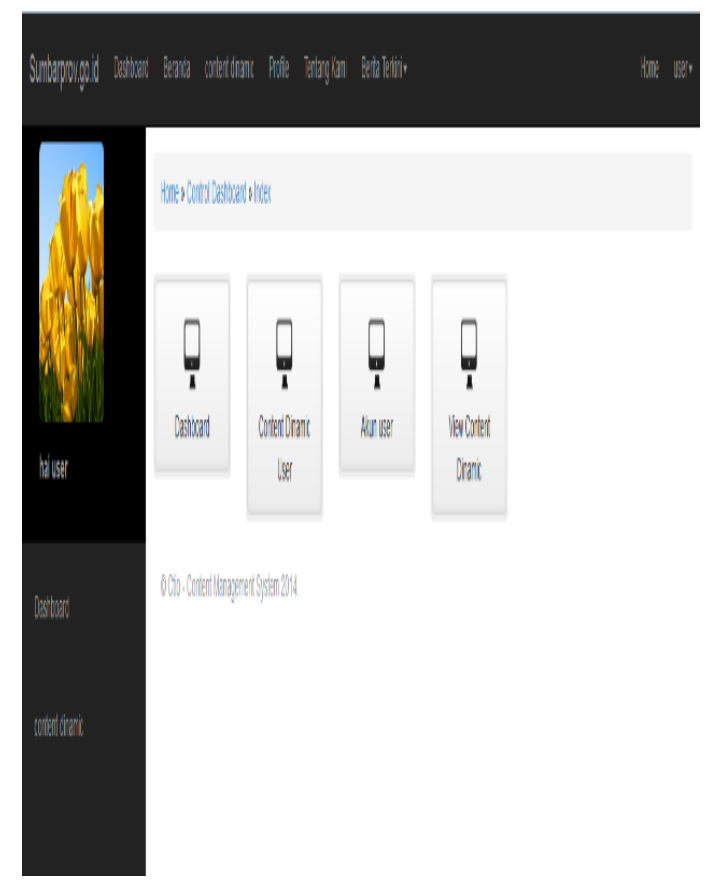

Gambar. 7 Halaman Dashboard Operator 


\section{Halaman Input Main Module}

Halaman Input Data Main Module dapat dilihat pada gambar 8 berikut :

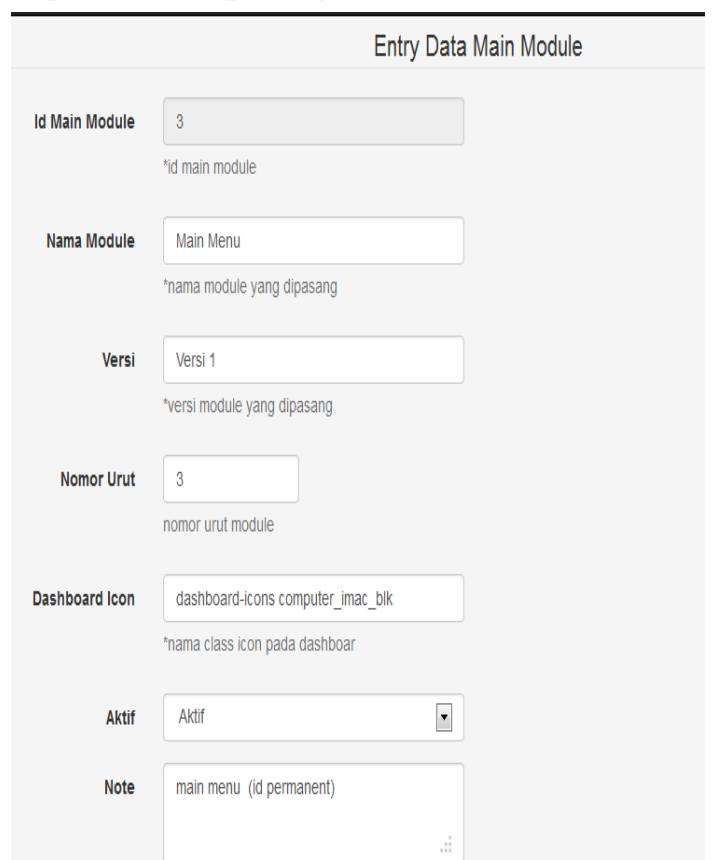

Gambar. 8 Halaman Input Data Main Module

\section{Halaman Input Module}

Halaman input data module dapat dilihat pada gambar 9 berikut

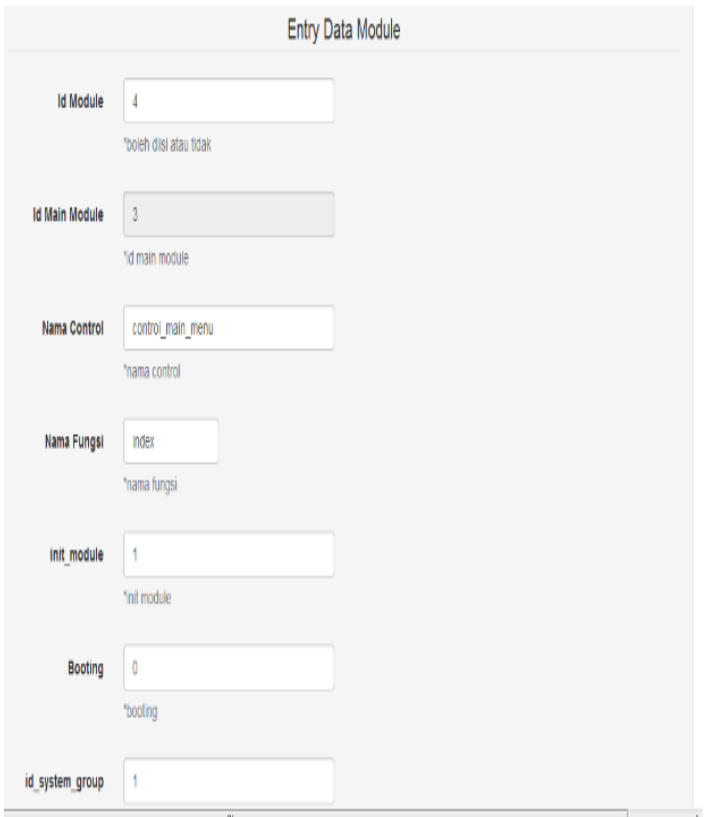

Gambar 9. Halaman Input Data Module

\section{Halaman Input Main Menu}

Halaman Input data main menu dapat dilihat pada gambar 10 berikut

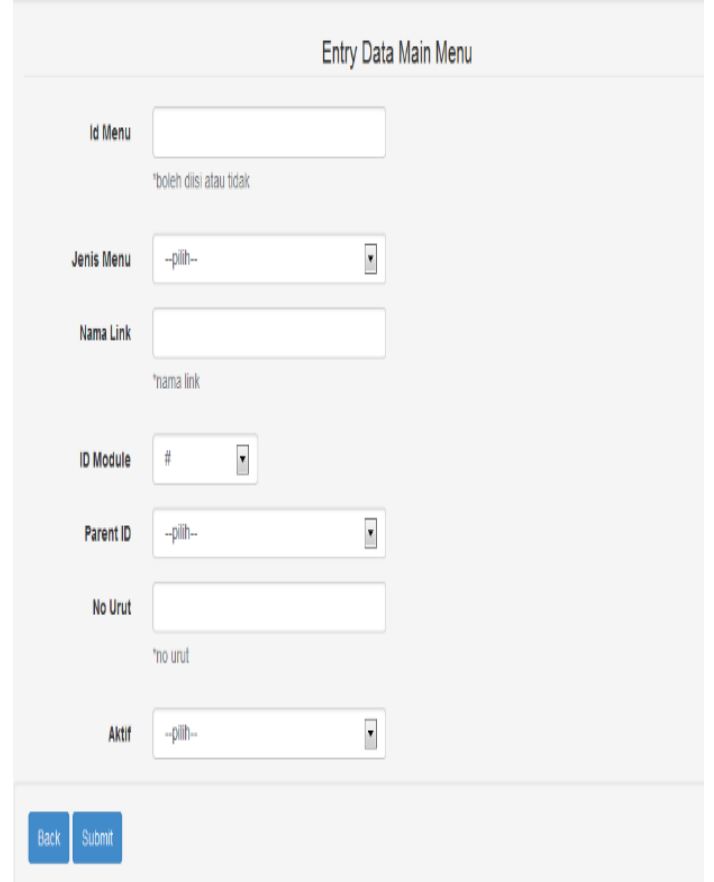

Gambar. 10 Halaman Input Data Main menu

\section{Halaman Input Sidebar Menu}

Halaman Input Data Sidebar Menu dapat dilihat pada gambar 11 berikut

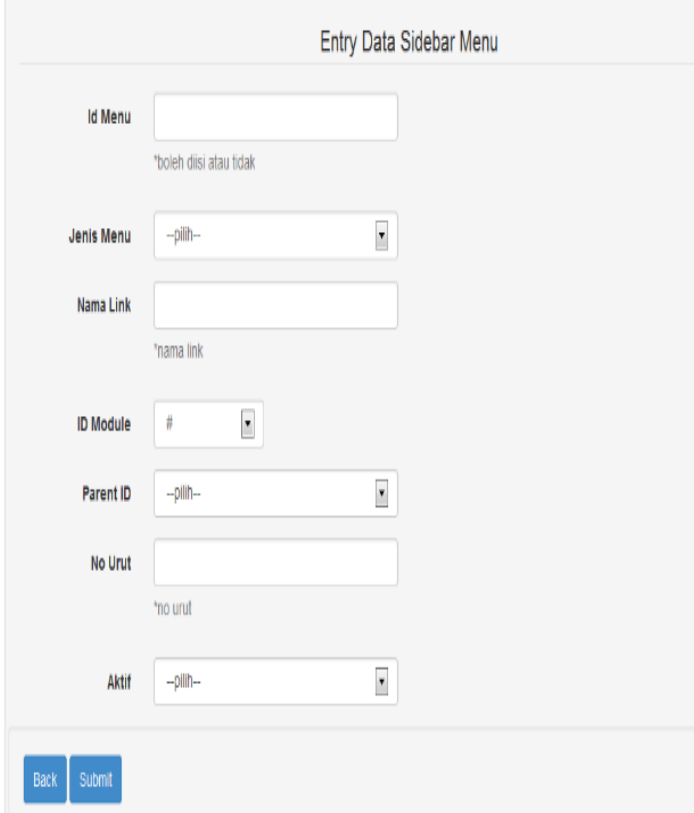

Gambar. 11 Halaman Input Data Sidebar Menu 


\section{Halaman Input User Menu}

Halaman Input Data User Menu dapat dilihat pada gambar 12 berikut

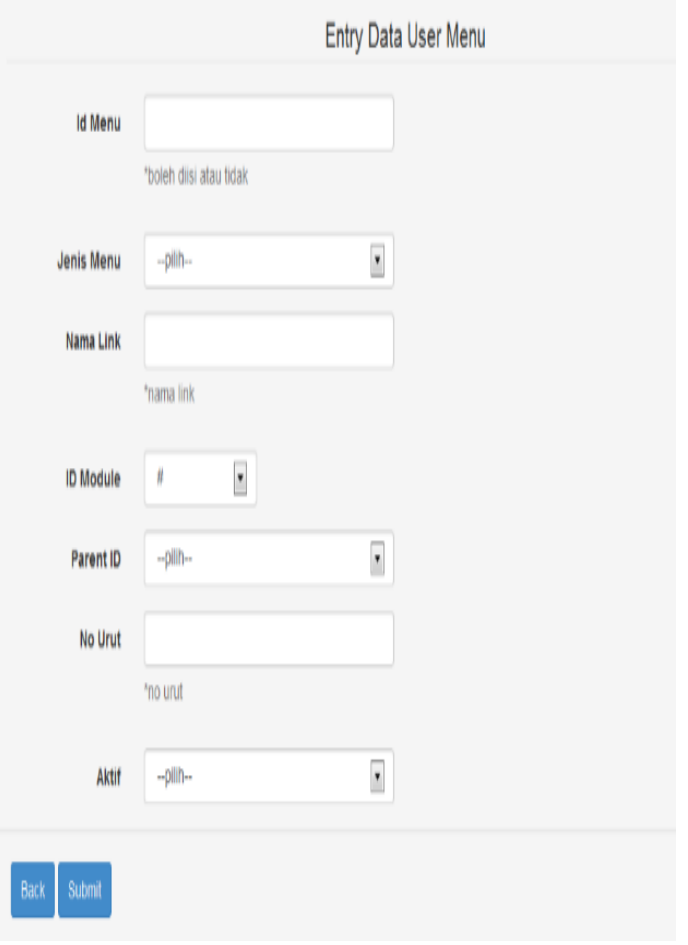

Gambar. 12 User Menu

\section{Halaman Input Data User}

Halaman input data user dapat dilihat pada gambar 13 berikut :

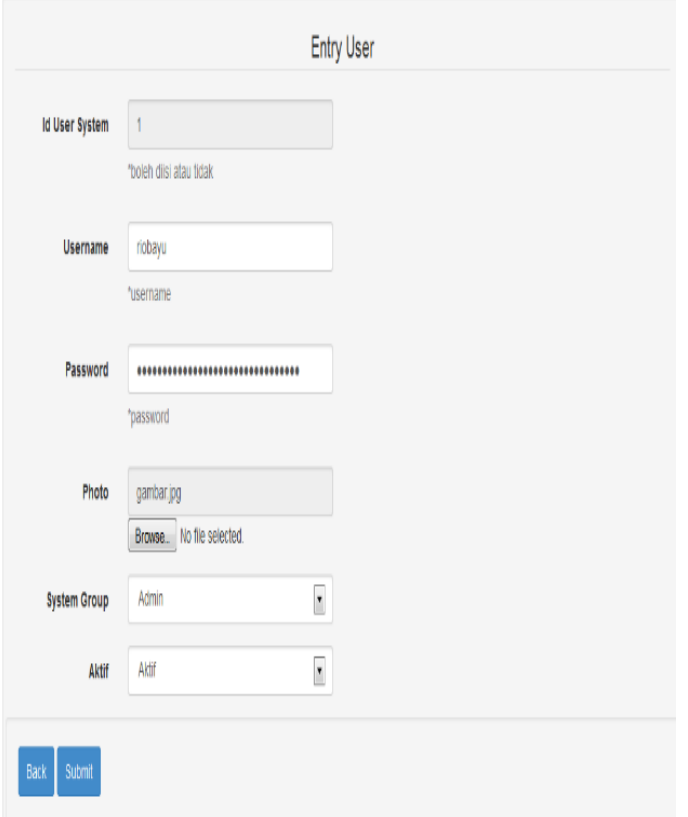

Gambar. 13 Halaman Input Data User

\section{Halaman Input Kategori}

Halaman input data kateogi dapat dilihat pada gambar 14 berikut :

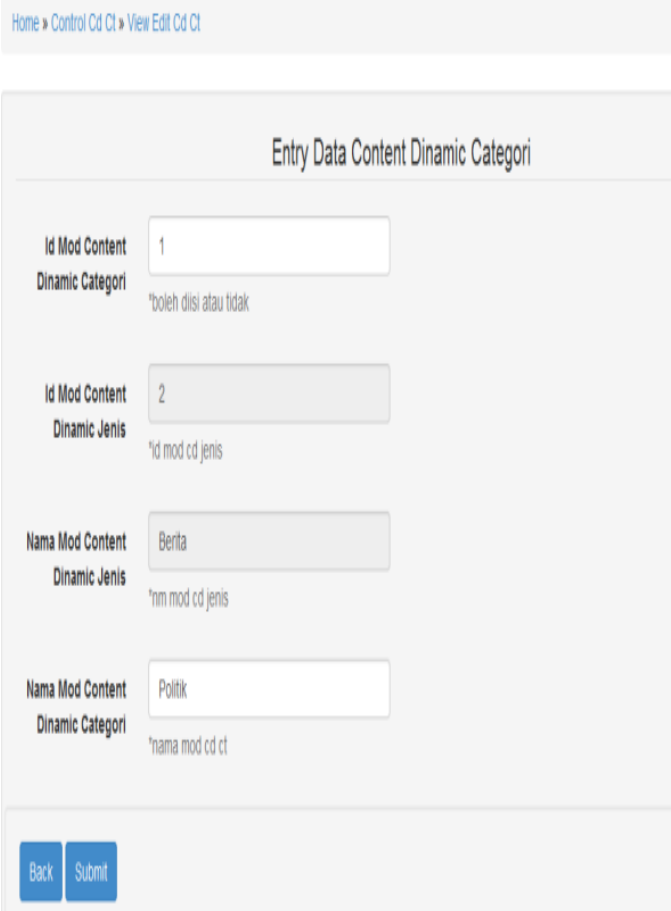

Gambar. 14 Halaman Input Data Kategori

\section{Halaman Input Content Dinamik}

Halaman input data content dinamik dapat dilihat pada gambar 15 berikut :

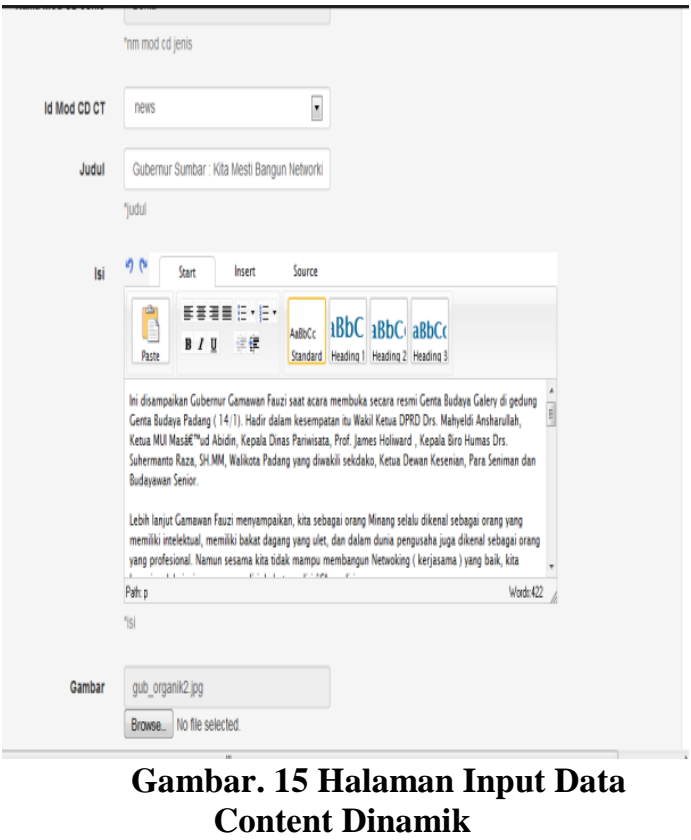




\section{Halaman Input Content Statis}

Halaman input data Content Statis dapat dilihat pada gambar 16berikut :

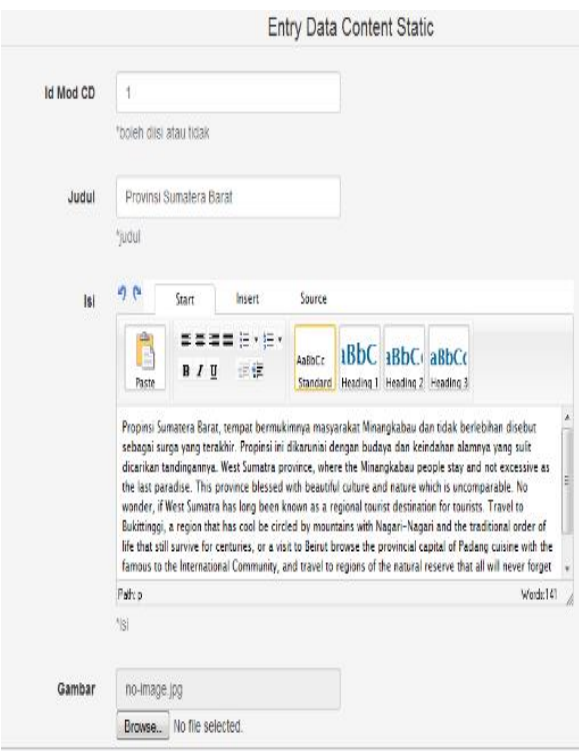

Gambar. 16 Halaman Input Data Content Statis

Dari halaman-halaman input data Administrator dalam memanajemen website dengan baik. Contoh dari bentuk laporan yang dihasilkan oleh Halaman Input data dapat dilihat pada gambar dibawah ini:

\section{Halaman List Main Module}

Main module dibutuhkan untuk memanajemen module-module seperti module menu, module user, module content yang akan ditampilkan pada halaman Dashboard. Halaman main module dapat dilihat pada gambar 17 berikut :

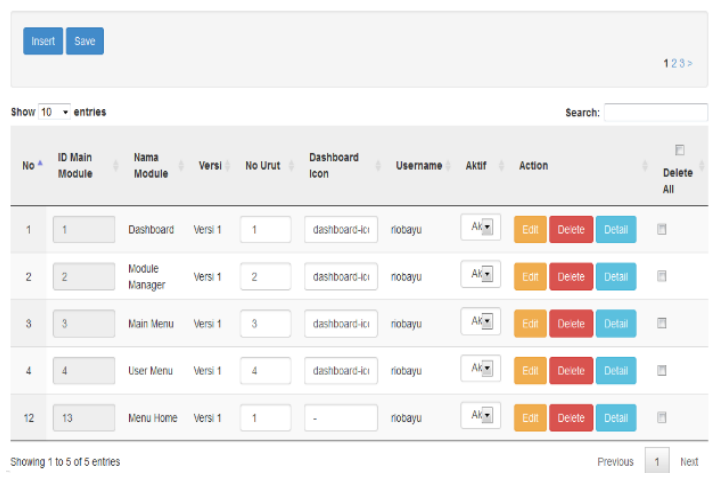

Gambar. 17 Halaman List Data Main Module

\section{Halaman List Module}

Module yang akan dibuat dikelompokkan dalam main module yang sebelumnya telah dibuat. Halaman list module dapat dilihat pada gambar 18 berikut :

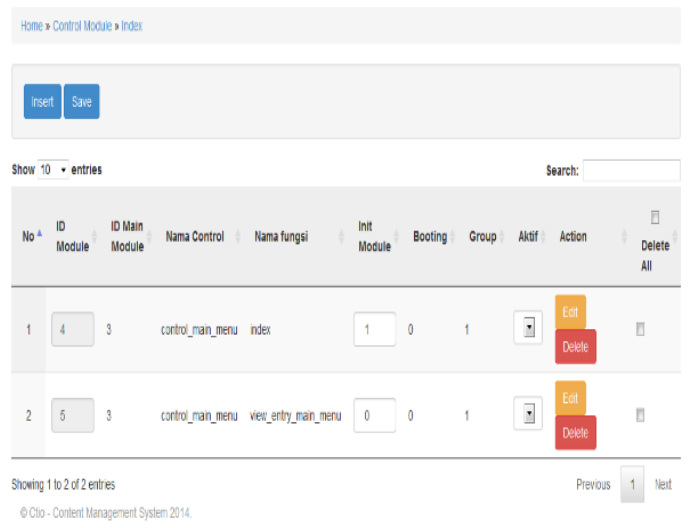

Gambar. 18 Halaman List Data Module

\section{Halaman List Main Manager}

Menu Manager digunakan untuk memanajemen main menu, sidebar menu, user menu. Main menu digunakan untuk menampilkan menu pada sisi atas, sidebar menu digunakan untuk menampilkan menu di sebelah kiri dan user menu untuk menampilkan menu untuk fasilitas user. Dapat dilihat pada gambar 19 berikut :

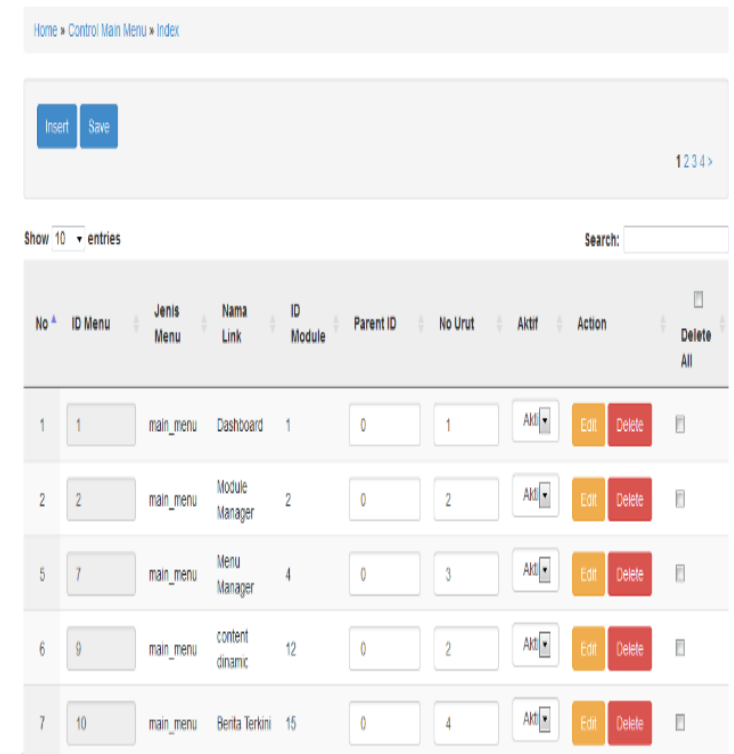

Gambar. 19 Halaman List Data Menu 


\section{Halaman List User Manager}

User manager adalah halaman untuk memanajemen user yang ada di dalam system, halaman User Manager dapat dilihat pada gambar 20 berikut :

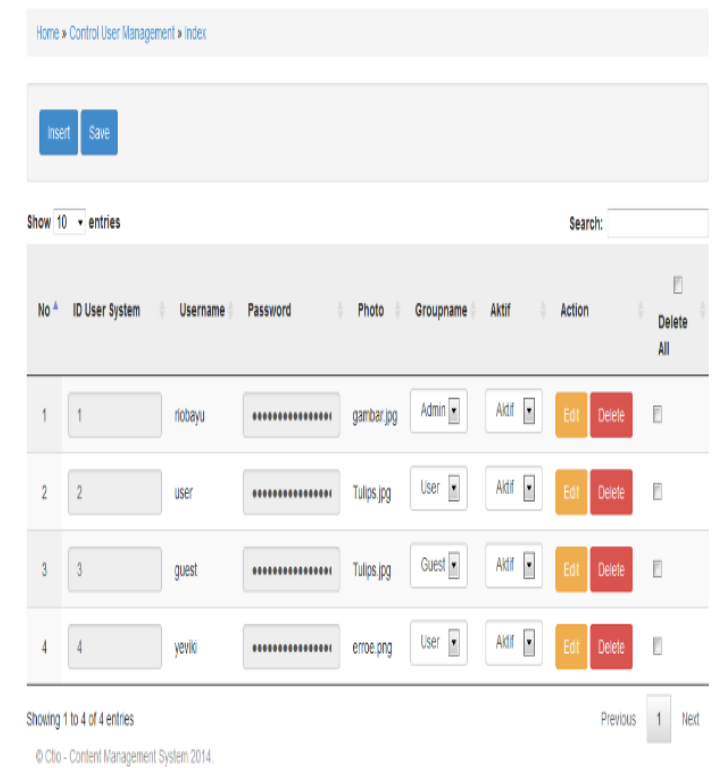

Gambar. 20 Halaman List Data User

\section{Halaman List Kategori}

Kategori digunakan oleh Content Dinamik dalam mempublikasikan berita, Halaman kategoridapat dilihat pada gambar 21 :

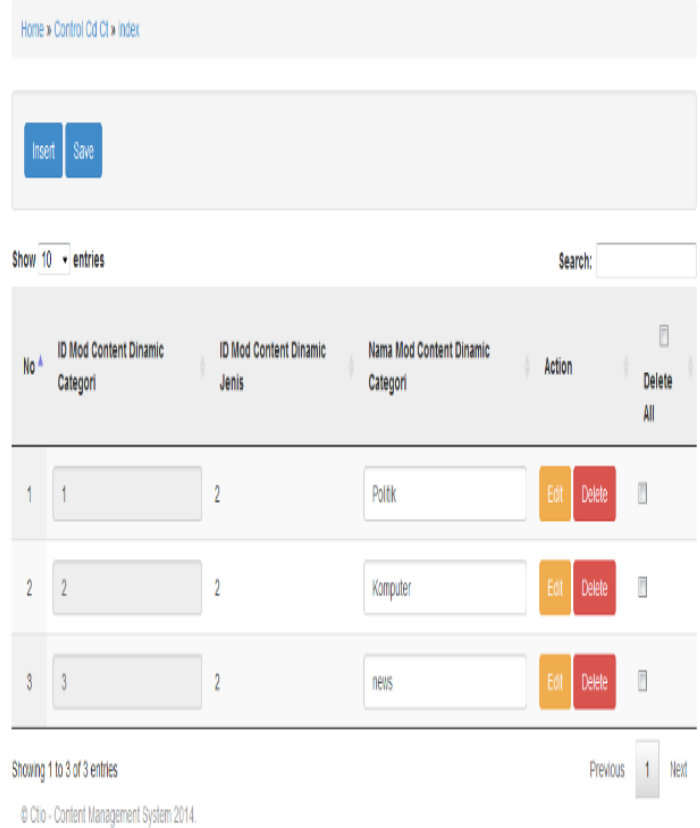

Gambar 21. Halaman List Data Kategori

\section{Halaman List Content Dinamik}

Content Dinamik digunakan untuk menyimpan data berita, dapat dilihat pada gambar 22 berikut :

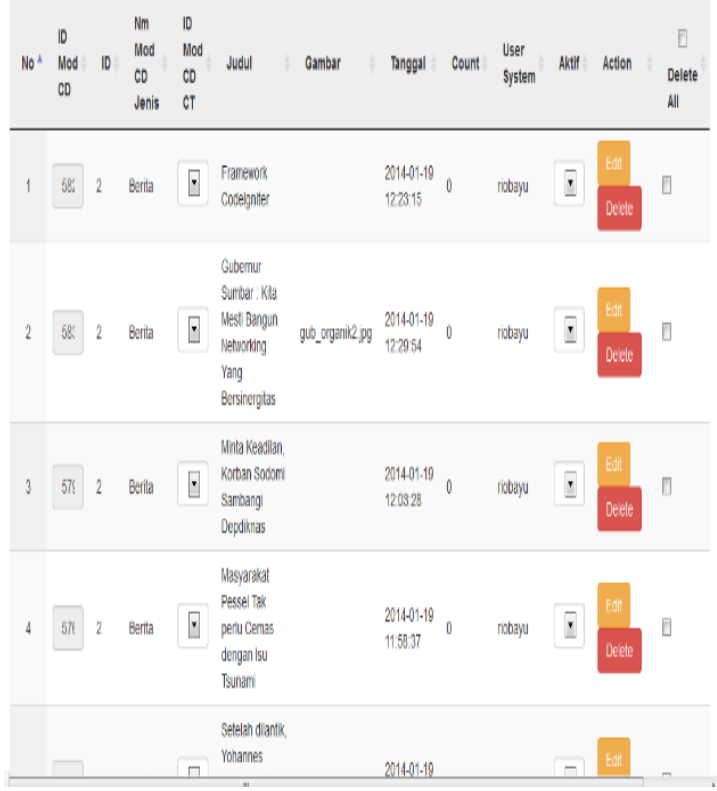

Gambar. 22 Halaman List Data Content Dinamik

\section{Halaman List Content Statis}

Content Static digunakan untuk menyimpan data statis berupa profil, alamat, visi dan misi Halaman Content Statis dapat dilihat pada gambar 23berikut :

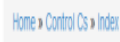
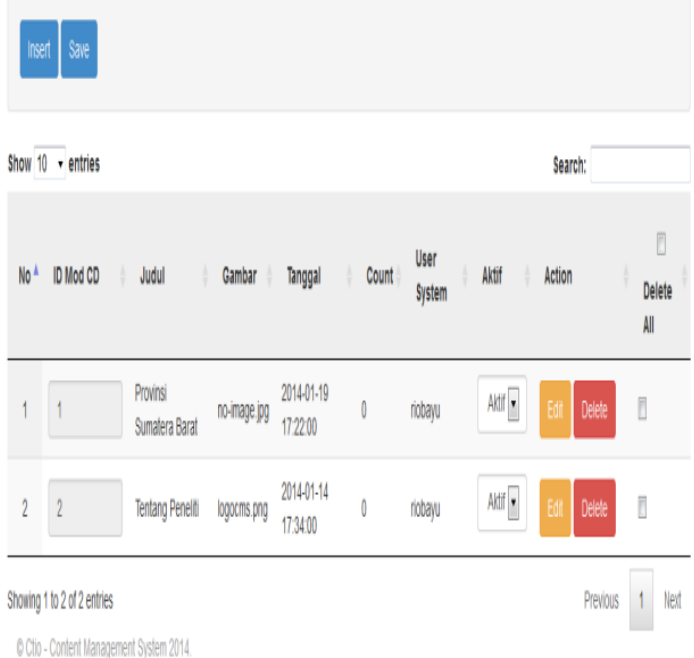

Gambar. 23 Halaman List Data Content Statis 


\section{SIMPULAN}

Adapun kesimpulan yang didapatkan dari penelitian ini adalah sebagai berikut :

1. Web Content Management System dengan standar basic Portal Berita yang penulis buat dapat melakukan penyeberan berita dengan baik.

2. Memberi akses yang cepat dan ringan saat pengaksesan halaman website.

3. Memberi Kemudahan kepada Administrator untuk memanjemen module-module baru ke dalam sistem yang dibutuhkan pada masa mendatang.

4. Framework CodeIgniter yang digunakan dalam pambuatan Aplikasi, dapat memberi kemudahan Developer pada masa mendatang dalam mengembangkan dan menyelesaikan system secara cepat khususnya aplikasi berbasis Rapid Application Development (RAD).

5. Sistem yang dirancang dapat dijadikan sebagai produk development yang memiliki nilai jual dimasa mendatang.

6. MariaDB sebagai media penyimpanan data dapat memuat data yang banyak dalam jangka waktu yang panjang.

7. Memberi Keamanan yang cukup baik dalam pengaksesan data yang dirancang berdasarkan level masingmasing. 


\section{DAFTAR PUSTAKA}

Al Fatta, H. (2007). Analisa dan Perancangan Sistem Informasi Untuk Keunggulan Bersaing Perusahan Organisasi Modern. Yogyakarta: Andi Offset

Hidayat, A., \& Surarso, B. (2012). Penerapan Arsitektur Model View Controller (MVC) dalam Rancang Bangun Sistem Kuis Online Adaptif. Seminar Nasional Teknologi Informasi dan Komunikasi

Octafian, D. T. (2015). Web Multi ECommerce Berbasis Framework Codeigniter. Jurnal Teknologi dan Informatika (Teknomatika), 5(1), $1-22$

Pamungkas, C. A. (2015). Pemanfaatan Codeigniter Framework dalam Membangun SMS Gateway Berbasis Gammu. Jurnal Informa Politeknik Indonusa Surakarta, 1(1), 1-10

Prabowo, D. (2015). Website ECommerce Menggunakan Model View Controller (MVC) dengen Framework Codeigniter. Jurnal Ilmiah DASI, 16(1), 23-39

Turban, E., Leidner, D., Mclean, E., \& Wetherbe, J. (2008). Information Technology for Management, Transforming Organizations in the Digital Economy. Jhon Wiley and Sons

Wardhani, D. R. (2011). Dukungan Database dalam Membangun Website yang Interaktif. Jurnal Ilmiah Faktor Exacta, 4(1), 29-36

Wibirama, S. (2007). Perancangan Pembuatan Content Management System (CMS) Laboraturium 'iLAB' menggunakan Framework CakePHP. Yogyakarta 